\title{
Identification and Expression of a Putative Facilitative Urea Transporter in Three Species of True Frogs (Ranidae): Implications for Terrestrial Adaptation
}

\author{
Andrew J. Rosendale, ${ }^{1,2}$ Jon P. Costanzo, ${ }^{1}$ Andor J. Kiss, ${ }^{1}$ and Richard E. Lee Jr. ${ }^{1}$ \\ ${ }^{1}$ Department of Zoology, Miami University, Oxford, OH 45056, USA \\ ${ }^{2}$ Department of Biology, Miami University, Oxford, OH 45056, USA
}

Correspondence should be addressed to Andrew J. Rosendale; rosendaj@miamioh.edu

Received 14 May 2014; Revised 1 July 2014; Accepted 3 July 2014; Published 23 July 2014

Academic Editor: Jesus L. Romalde

Copyright (c) 2014 Andrew J. Rosendale et al. This is an open access article distributed under the Creative Commons Attribution License, which permits unrestricted use, distribution, and reproduction in any medium, provided the original work is properly cited.

\begin{abstract}
Urea transporters (UTs) help mediate the transmembrane movement of urea and therefore are likely important in amphibian osmoregulation. Although UTs contribute to urea reabsorption in anuran excretory organs, little is known about the protein's distribution and functions in other tissues, and their importance in the evolutionary adaptation of amphibians to their environment remains unclear. To address these questions, we obtained a partial sequence of a putative UT and examined relative abundance of this protein in tissues of the wood frog (Rana sylvatica), leopard frog (R. pipiens), and mink frog (R. septentrionalis), closely related species that are adapted to different habitats. Using immunoblotting techniques, we found the protein to be abundant in the osmoregulatory organs but also present in visceral organs, suggesting that UTs play both osmoregulatory and nonosmoregulatory roles in amphibians. UT abundance seems to relate to the species' habitat preference, as levels of the protein were higher in the terrestrial $R$. sylvatica, intermediate in the semiaquatic $R$. pipiens, and quite low in the aquatic $R$. septentrionalis. These findings suggest that, in amphibians, UTs are involved in various physiological processes, including solute and water dynamics, and that they have played a role in adaptation to the osmotic challenges of terrestrial environments.
\end{abstract}

\section{Introduction}

During periods of osmotic stress, amphibians accumulate various balancing osmolytes that help them maintain water balance. Urea, the major end product of nitrogen metabolism in most amphibians, is an organic solute which is usually maintained at relatively low levels in amphibians; however, desiccating or hypersaline conditions will result in urea accumulation $[1,2]$. High levels of urea in the body fluids reduce water loss and improve ability to survive osmotic stresses $[1,2]$ while at the same time replacing ionic solutes that are more detrimental to the animal [3]. Hyperuremia also contributes to winter survival in certain terrestrially hibernating frogs [4-6].

In amphibians, urea accumulation occurs by increasing the synthesis of urea by altering urea-cycle activity and/or increasing the retention of urea [7]. The latter can be accomplished by decreasing urine production through a reduction in glomerular filtration rate and by reabsorbing urea from the filtrate in the kidneys and urinary bladder $[8$, 9]. Growing evidence suggests the involvement of transport proteins, specifically facilitative urea transporters (UTs), in the reabsorption process [10-12], but the specific roles of these proteins require additional investigation.

UTs are present in a broad diversity of organisms including mammals [13], fish [14], reptiles [15], and anuran amphibians $[10,11]$. These proteins are most extensively studied in mammals wherein two distinct groups have been identified, UT-A and UT-B [13]. These proteins have various physiological roles ranging from urine concentration in the kidney to nitrogen recycling in the intestine (reviewed in [16]). Much less is known about UTs in anurans; however, these proteins have been found in the urinary bladder and early distal tubule $[10,11]$, suggesting they function in 
reabsorbing urea from the filtrate. Utilization of UTs in urea reabsorption may be especially important during periods of osmotic stress, as the expression of UTs increases in response to desiccation and hypersaline conditions $[11,12]$.

Although UTs have been implicated in the reabsorption of urea in the kidney and urinary bladder of anurans $[10,11]$, little is known about these proteins in other tissues, and the general importance of UTs in surviving in osmotically challenging environments remains unclear. To elucidate the potential physiological roles of UTs in anurans, we examined the tissue distribution and abundance of a putative UT isolated from the urinary bladder of three species of true frogs, Rana sylvatica, $R$. pipiens, and $R$. septentrionalis, which differ markedly in their hydric requirements and, thus, susceptibility to osmotic stress. By investigating frogs with distinct natural histories, we gained new insights into the importance of UTs in amphibian adaptation to terrestrial environments.

\section{Materials and Methods}

2.1. Animals. Male R. sylvatica were collected from a vernal pool in southern Ohio (Adams County) during March, 2008, and transported to our laboratory where they were maintained in the dark on damp moss at $4^{\circ} \mathrm{C}$. In early April, the frogs were transferred to a $48 \mathrm{~m}^{2}$ outdoor enclosure in a wooded area of the Miami University Ecological Research Center. They were fed crickets three times each week and had continuous access to water. In late October, frogs were recaptured, brought to the laboratory, and kept unfed on damp moss in darkened boxes at $4^{\circ} \mathrm{C}$ until used in experiments in late January.

Male $R$. pipiens collected in autumn from populations in northern Minnesota were obtained commercially (TransMississippi Biological Supply, Shoreview, MN) in early February. Frogs were kept unfed at $4^{\circ} \mathrm{C}$ in darkened boxes with access to dechlorinated tap water for 2 weeks before being used in experiments.

Male R. septentrionalis were collected in early August from populations in northern Maine (Somerset County) and shipped to our laboratory. Frogs were kept unfed at $15^{\circ} \mathrm{C}$ with access to dechlorinated tap water $(14: 10, \mathrm{~L}: \mathrm{D})$ for 2 weeks before being used in experiments.

Frogs were euthanized by double pithing, and tissues were quickly removed. Urinary bladder, kidney, skin, stomach, large intestine, small intestine, liver, lung, and skeletal muscle were collected, frozen in liquid $\mathrm{N}_{2}$, and stored at $-80^{\circ} \mathrm{C}$ until analyzed. Aortic blood was collected into heparinized capillary tubes, which was centrifuged at $2000 \times \mathrm{g}$ for $5 \mathrm{~min}$ to isolate plasma, which was frozen in liquid $\mathrm{N}_{2}$ and stored at $-80^{\circ} \mathrm{C}$ until analyzed. Plasma concentration of urea was determined colorimetrically using urease (Pointe Scientific, Canton, MI, USA).

All experiments were conducted in compliance with the Institutional Animal Care and Use Committee at Miami University.

2.2. Total RNA and Protein Isolation. Total RNA and protein were extracted from the tissues using Trizol (Invitrogen,
Carlsbad, CA). Briefly, up to $100 \mathrm{mg}$ of tissue was homogenized in $1 \mathrm{~mL}$ Trizol reagent using a shearing-type homogenizer (model 985370, BioSpec Products, Bartlesville, OK). Following a $5 \mathrm{~min}$ incubation at room temperature (RT; $22^{\circ} \mathrm{C}$ ), $0.2 \mathrm{~mL}$ chloroform was added, and the solution was centrifuged at $12,000 \mathrm{~g}$ for $15 \mathrm{~min}$ at $4^{\circ} \mathrm{C}$. The aqueous phase containing the RNA was transferred to a fresh tube, and the protein was isolated from the remaining solution as described below. RNA was precipitated by adding $0.5 \mathrm{~mL}$ isopropanol, incubating for $10 \mathrm{~min}$ at RT, and then centrifuging at $12,000 \mathrm{~g}$ for $10 \mathrm{~min}$ at $4^{\circ} \mathrm{C}$. The RNA pellet was washed with $1 \mathrm{~mL}$ of $75 \%$ ethanol, air-dried, and redissolved in 50-100 $\mu \mathrm{L}$ RNasefree water. RNA quality was confirmed by checking the optical density ratio at $260: 280 \mathrm{~nm}$ [16].

Following chloroform extraction of the RNA, DNA was precipitated by adding $0.3 \mathrm{~mL}$ of ethanol and centrifuging at $2,000 \mathrm{~g}$ for $5 \mathrm{~min}$. The supernatant containing protein was transferred to a fresh tube, and protein was precipitated by adding $1.5 \mathrm{~mL}$ isopropanol and centrifuging at 12,000 $\mathrm{g}$ for $10 \mathrm{~min}$ at $4^{\circ} \mathrm{C}$. The protein pellet was washed three times by adding $2 \mathrm{~mL}$ of $0.3 \mathrm{M}$ guanidine hydrochloride in $95 \%$ ethanol, incubating at RT for $20 \mathrm{~min}$, and centrifuging at $7,500 \mathrm{~g}$ for $5 \mathrm{~min}$ at $4^{\circ} \mathrm{C}$. After the final wash, $2 \mathrm{~mL}$ of ethanol was added and the pellet was incubated at RT for $20 \mathrm{~min}$, followed by a centrifugation $(7,500 \mathrm{~g})$ for $5 \mathrm{~min}$ at $4^{\circ} \mathrm{C}$. The pellet was air-dried and protein was resuspended in 50$100 \mu \mathrm{L}$ of $8 \mathrm{M}$ urea.

2.3. cDNA Cloning of Partial UT cDNA. cDNA was reversetranscribed from $5 \mu \mathrm{g}$ total RNA from urinary bladder tissue using an oligo (dT)-adaptor primer ( $5^{\prime}$-GGC CAC GCG TCG ACT AGT ACT (dT) $)_{15}-3^{\prime}$; Integrated DNA Technologies, Coralville, IA) following the manufacturer's protocol (Reverse Transcription System, Promega, Madison, WI). The cDNA template was used in a polymerase chain reaction (PCR) using a degenerate sense primer $\left(5^{\prime}\right.$ GGTSATGTTTGTCARCAATCCTCTSAGTGGACTC- $3^{\prime}$ ) designed from an area of conserved amino acid sequence from other UTs of amphibians, including Bufo marinus (accession number AB212932) and Rana esculenta (accession number Y12784), and an anti-sense $3^{\prime}$ adaptor primer $\left(5^{\prime}\right.$ GGCCACGCGTCGACTAGTAC-3'). PCR was performed in $25 \mu \mathrm{L}$ GoTaq Green Master Mix (Promega) containing $0.2 \mathrm{mM}$ dNTP, $1.5 \mathrm{mM} \mathrm{MgCl}_{2}, 0.4 \mu \mathrm{M}$ of each primer, 0.625 units of GoTaq DNA polymerase, and $2 \mu \mathrm{L}$ firststrand cDNA. PCR was performed in a Veriti thermal cycler (Applied Biosystems, Foster City, CA) with an initial denaturation step of $94^{\circ} \mathrm{C}$ for $3 \mathrm{~min}$, followed by 30 cycles of denaturation $\left(94^{\circ} \mathrm{C}, 1 \mathrm{~min}\right)$, annealing $\left(55^{\circ} \mathrm{C}, 30 \mathrm{~s}\right)$, and extension $\left(72^{\circ} \mathrm{C}, 1 \mathrm{~min}\right)$, with a final extension step of $72^{\circ} \mathrm{C}$ for $10 \mathrm{~min}$. A PCR product of $1000 \mathrm{bp}$ was ligated into the pGEM-T Easy plasmid cloning vector following the manufacturer's instructions (Promega), transformed into JM109strain Escherichia coli, and plated on LB-ampicillin agar containing isopropyl $\beta$-D-1-thiogalactopyranoside and 5bromo-4-chloro-3-indolyl- $\beta$-D-galactopyranoside. Plasmid DNA was prepared using High-speed Mini columns (IBI Scientific, Peosta, IA). The sequencing reaction was performed using the BigDye Terminator v3.1 Cycle Sequencing 
Kit (Applied Biosystems) and standard T7 or SP6 sequencing primers (Promega). Sequences were analyzed on a 3130xl Genetic Analyzer (Applied Biosystems). One partial UT sequence was identified for each species (Rsy-UT, Rp-UT, and Rse-UT) by comparing the obtained sequences to those published in GenBank (National Center for Biotechnology Information) using nucleotide comparison (BLASTN).

To obtain the $5^{\prime}$ end of the UT sequence, rapid amplification of cDNA end (RACE) technique was used. The $5^{\prime}$ end was amplified with PCR following the manufacturer's instructions ( $5^{\prime}$-RACE v2.0 Kit, Invitrogen). Briefly, cDNA was synthesized as described above and purified using a silica-based S.N.A.P. centrifugation column. A poly $(\mathrm{C})^{+}$tail was attached to the $3^{\prime}$ end of the cDNA in a $25 \mu \mathrm{L} \mathrm{TdT}$ tailing reaction containing $10 \mu \mathrm{L} c \mathrm{cNA}, 1 \mu \mathrm{L}$ TdT, and a final composition of $10 \mathrm{mM}$ Tris- $\mathrm{HCl}, 25 \mathrm{mM} \mathrm{KCl}, 1.5 \mathrm{mM}$ $\mathrm{MgCl}_{2}$, and $200 \mu \mathrm{M} \mathrm{dCTP}$. Tailed cDNA was used in a PCR reaction using gene-specific, antisense primers (Rsy-UT and Rp-UT 5 '-CGGCGATATTGAAAGGCAGCGT-3'; Rse-UT $5^{\prime}$-ACAGCGATATTGAAAGGCAGCGTG-3) and an oligo $(\mathrm{dG})$ sense primer. The $500 \mathrm{bp}$ product was cloned and sequenced as described above. The cDNA sequences for Rsy-UT, Rp-UT, and Rse-UT were submitted to GenBank (accession numbers JF755889, JF755890, and JF755891, resp.).

2.4. Phylogenetic Analysis. Relatedness of our novel UT sequences in the context of previously reported UTs was determined by phylogenetic analysis. Complimentary DNA sequences were translated in silico and aligned using ClustalX 2.1 employing the Gonnet weight matrix. Using the amino acid alignment, cDNA nucleotides were aligned using a codon-constraint approach implemented by CodonAlign2.0 [17] and model selection was done using MrModelTest2.3 [18] in PAUP4.0*b10. Tree construction was done by MrBayes3.1.2 using a "Generalized Time Reversible plus Invariant" (GTR+I) evolutionary model [19] as chosen by MrModelTest2.3. Four runs using four chains and $10,000,000$ generations were performed. All other parameters in MrBayes 3.1.2 were left at default. Stationarity was assessed using the "sump burnin=250" command and by examining the plot of the generation versus the log likelihood values. A 50\% majority rule consensus tree was generated using the command "sumt burnin=250". A Newick tree file, including branch lengths and Bayesian consensus values, was imported into the tree explorer of MEGA5 [20] to draw the phylogram.

2.5. Antibody. An oligopeptide was designed from the C-terminal amino acids 364-383 (LSKVTYPEDNRIYYLNLKKE) of the ranid UT (Figure 1). The peptide was synthesized with an amino-terminal cysteine residue, and a polyclonal UT antibody was raised commercially (Proteintech Group, Chicago, IL) in rabbit. The antiserum was purified with a SulfoLink Immobilization Kit (Pierce Protein Research Products, Rockford, IL) following the manufacturer's protocol.

2.6. Immunoblot Analysis. Urinary bladder, kidney, skin, stomach, large intestine, small intestine, liver, lung, and skeletal muscle were homogenized in Trizol as described above. Final protein concentration was determined using the Bradford protein assay (Bio-Rad, Hercules, CA). To improve solubility, protein samples $(30 \mu \mathrm{g})$ were incubated at $95^{\circ} \mathrm{C}$ for $15 \mathrm{~min}$ and incubated at $37^{\circ} \mathrm{C}$ until sample buffer was added ( $\sim 5 \mathrm{~min}$ ). Samples were mixed with Laemmli sample buffer (Bio-Rad) containing 5\% $\beta$-mercaptoethanol and incubated at $50^{\circ} \mathrm{C}$ for $15 \mathrm{~min}$ and analyzed by SDS-PAGE on a $4-15 \%$ gradient gel (Bio-Rad). Precision Plus Protein standard (Bio$\mathrm{Rad}$ ) and MagicMark XP protein standard (Invitrogen) were used as a size reference.

Following electrophoresis, proteins were transferred to a nitrocellulose membrane (Bio-Rad). To ensure that we achieved equal loading across lanes and equivalent transfer, membranes were stained with $0.2 \%$ Ponceau S (w/v) (Sigma Chemical Company, St. Louis, MO) containing 5\% acetic acid. After the membranes were digitally scanned, they were destained using $0.1 \mathrm{M} \mathrm{NaOH}$. Nonspecific protein antigens were blocked at $4^{\circ} \mathrm{C}$ overnight in TBS-T (10 mM Tris, $100 \mathrm{mM}$ $\mathrm{NaCl}$, and $0.1 \%$ Tween 20 at $\mathrm{pH} 7.5$ ) containing $10 \%$ nonfat milk. The membranes were incubated with the anti-UT primary antibody $(1 \mu \mathrm{g} / \mathrm{mL})$ in TBS-T containing $5 \%$ nonfat milk overnight at $4^{\circ} \mathrm{C}$. The membranes were washed 3 times in TBS-T for $15 \mathrm{~min}$ each time and then incubated for $2 \mathrm{~h}$ at RT with goat anti-rabbit IgG-HRP conjugates secondary antibody (GE Healthcare, Piscataway, NJ) diluted 1:1000 in TBS-T containing 5\% nonfat milk. Membranes were then washed in TBS-T, incubated for $2 \mathrm{~min}$ in ECL (enhanced chemiluminescence) detection reagents (GE Healthcare), and exposed to autoradiography film. To check specificity, the anti-UT antibody was exposed to a molar excess of its antigenic peptide in a competition assay. All samples were run in duplicate; the average of the two densitometric values was then used in statistical analyses. Radiography films were digitally scanned, and bands were semiquantified using AlphaViewspot densitometry (Alpha Innotech). UT abundance was compared among tissues within a species $(n=$ 4 individuals per species) by loading each gel with at least one sample representing each tissue. Protein abundance was compared among species ( $n=5$ individuals per species) by loading all samples from a single tissue from each species.

2.7. Quantitative Real-Time PCR. Quantitative real-time PCR (qPCR) was performed on urinary bladder, kidney, skin, and skeletal muscle from each species. Total RNA was extracted from tissues using Trizol as described above. Total RNA was reverse-transcribed using the GoScript Reverse Transcription System (Promega). Each reaction contained GoScript reaction buffer, $1 \mu \mathrm{g}$ RNA, $0.5 \mu$ g random primers, $4 \mathrm{mM} \mathrm{MgCl}_{2}, 0.5 \mathrm{mM} \mathrm{dNTP}$, and GoScript Reverse Transcriptase. qPCR reactions $(25 \mu \mathrm{L})$ were performed using GoTaq qPCR Master Mix (Promega) with $5 \mu \mathrm{L}$ of the cDNA sample (diluted 1:10), nuclease-free water, and UT $(100 \mathrm{nM})$ or GAPDH $(50 \mathrm{nM})$ primers. For these reactions, primers specific to the ranid UT (sense $5^{\prime}$-GTTTGTCTGCACTTGGCTGCCACTG-3', antisense $5^{\prime}$-GTATACTTGCCCCACACCGACCG-3') were utilized. Primers specific for the gene glyceraldehyde 
3-phosphate dehydrogenase (GAPDH) (sense $5^{\prime}$ CTTGAAGGGAGGTGCCAAGCGT- $3^{\prime}$, antisense $5^{\prime}$ ACCTTTGCAAGAGGAGCCAG- $3^{\prime}$ ) were designed from regions of identical nucleotide sequence among Xenopus laevis (accession no. AF549496), X. tropicalis (accession no. BC075438), and Rana rugosa (accession no. AB284116). In a validation experiment [21], the optimal concentration of each primer set was determined over a 10x dilution series of cDNA, and we found that the amplification efficiencies for UT (92.3\%) and GAPDH (92.9\%) were similar among primers sets. qPCR reactions were analyzed using an iCycler thermal cycler (BioRad). Reactions consisted of a hot-start activation at $95^{\circ} \mathrm{C}$ for $5 \mathrm{~min}$, followed by 45 cycles of denaturation at $95^{\circ} \mathrm{C}$ for $10 \mathrm{~s}$, annealing/extension at $60^{\circ} \mathrm{C}$ for $30 \mathrm{~s}$, and denaturation $95^{\circ} \mathrm{C}$ for $1 \mathrm{~min}$. Following amplification, a melt-curve analysis was performed from $65^{\circ} \mathrm{C}$ to $95^{\circ} \mathrm{C}$ with $0.5^{\circ} \mathrm{C}$ increments every $10 \mathrm{~s}$. Each sample was run in triplicate, and the average quantification cycle (Cq) value was determined. A negative control (-reverse transcriptase) was run for each sample to check for genomic DNA contamination and a no-template control was run with each primer pair to check for primer-dimers and reagent contamination. UT mRNA levels were normalized to GAPDH using the $\Delta \Delta \mathrm{C}_{\mathrm{T}}$ method as previously described [21].

2.8. Statistical Analysis. All values are reported as means \pm SEM. Significant differences in protein and mRNA levels among tissues were determined by an ANOVA with a Tukey's test. Differences were considered significant at $P<0.05$.

\section{Results}

3.1. Cloning of Ranid UTs. A putative UT was cloned from the bladders of R. sylvatica (Rsy-UT), R. pipiens (Rp-UT), and $R$. septentrionalis (Rse-UT) with sequence lengths of $1172 \mathrm{bp}, 1169 \mathrm{bp}$, and $1170 \mathrm{bp}$, respectively. A putative openreading frame encodes a protein of 386 amino acids for each species (GenBank accession numbers AFE48181, AFE48182, and AFE48183; Figure 1(a)). One putative N-glycosylation site was identified for each protein at amino acids 211-213. Hydropathy analysis of each protein predicted ten transmembrane regions with the $\mathrm{N}$ and $\mathrm{C}$ termini positioned in the cytoplasm (Figure 1(b)). The three proteins did not differ noticeably in their hydropathy plots.

These proteins showed a high degree of amino acid identity with their homologues in R. esculenta (94-95\%) and Bufo marinus (79\%) and also share identity with mammalian UT-A2 (71\%) and UT-B (63-66\%). Phylogenetic analysis of the three newly characterized UTs (Rs-UT, Rp-UT, and RseUT) demonstrated that these transporters group with those previously reported from the edible frog $R$. esculenta and cane toad $B$. marinus to form a distinct clade sister to the mammalian isoforms, UT-A2 and UT-A3 (Figure 2).

3.2. Tissue Distribution and Abundance of UT. The tissue distribution of the UT protein was determined using immunoblot techniques. A polyclonal antibody designed against a portion of the ranid UT corresponding to the Cterminus region was used to probe total protein extracted from urinary bladder, kidney, skin, stomach, large intestine, small intestine, liver, lung, and skeletal muscle. In tissue from all three species, a band was detected at $60 \mathrm{kDa}$ (Figures 3 and 4), a mass similar to that reported for the UTs from other lower vertebrates $[11,15]$. In R. sylvatica and, to a lesser extent, $R$. septentrionalis, several bands of higher molecular mass were also detected (Figure 3). These bands persisted when samples were treated with $\mathrm{N}$-glycanase (data not shown), suggesting they were not the result of glycosylation of the UT protein. To determine if they were the result of phosphorylation, Pro-Q Diamond Phosphoprotein Stain (Invitrogen) was used following the manufacturer's protocol; however, we detected no distinct phosphorylated bands that matched our immunoblotted bands (data not shown). Some evidence suggested that the extraneous bands were the result of nonspecific binding. The presence, molecular mass, and intensity of the extraneous bands varied among tissues. Furthermore, when the anti-UT antibody was preincubated with its antigenic peptide in a competition assay, the primary band $(60 \mathrm{kDa})$ was completely ablated while some of the extraneous bands remained (Figure 3(D)). Therefore, we included only the bands at $60 \mathrm{kDa}$ in subsequent analyses. In separate statistical analyses, we determined that including the higher molecular weight bands raised the relative protein levels by $\sim 20 \%$ but did not materially affect our conclusions, so the analysis of only the $60 \mathrm{kDa}$ bands was utilized.

In all species, the relative abundance of UT differed qualitatively among the sampled tissues, with the bladder having the greatest abundance of the protein (Figure 4). Conversely, skeletal muscle had no detectable amount of UT protein in any of the species tested. It was barely detectable in the skin of $R$. pipiens and $R$. septentrionalis, but modest amounts of the protein occurred in most of the other tissues examined.

The species varied markedly in UT abundance in bladder ( $F=86.5, P<0.0001)$, kidney $(F=25.4, P<0.0001)$, and skin $(F=20.5, P<0.0001)$, but not in liver $(F=3.6, P=$ $0.059)$. In bladder, UT abundance was greatest in R. sylvatica, intermediate in $R$. pipiens, and lowest in $R$. septentrionalis (Figure 5 ). In kidney and skin, UT was vastly more abundant in R. sylvatica as compared to R. pipiens and R. septentrionalis.

3.3. mRNA Expression. To determine if tissue- and speciesspecific trends in protein amounts were also observed in mRNA levels, qPCR was performed on RNA isolated from urinary bladder, kidney, skeletal muscle, and skin of each species. Relative mRNA amounts were determined using the $\Delta \Delta \mathrm{C}_{\mathrm{t}}$ method and mRNA levels were expressed relative to R. sylvatica bladder. Measureable levels of UT mRNA were detected in all tissues examined, with the exception of skeletal muscle of $R$. septentrionalis. UT mRNA levels varied among tissues, being highest in urinary bladder (R.pipiens) or kidney (R. sylvatica) (Table 1). Qualitatively, positive correlations between protein and mRNA levels were observed. For example, no UT protein was detected in skeletal muscle, the tissue exhibiting the lowest level of mRNA expression. Additionally, 
Rsy UT MESHIPINMAEKEVKKPVESPNHCSSSLGLFCTGINYISGEMKEFGNWLKDKPIIFQFIDWVLRGASQVMFVSNPLSGLI Rp UT MESHIPINMAEKEGKKPVESPNHCSGSLGLFCTAIHYISGEMKEFGNWLKDKPIIFQFIDWVLRGASQVMFVSNPLSGLI Rse UT MESHIPINMAEKEGKKPAESPNHCSSSLGLFCTAIHYISGEMKEFGNWLKDKPIIFQF IDWVLRGASQVMFVSNPLSGLI Re UT MESHIPINMAEKELKKPVESPNHCSSGLGFFCTAIHYISGEMKEFGNWLKDKPIIFQF IDWVLRGASQVMFVSNPLSGLI Mm UT-A2 MEESTEIKVEANTARTSWIQSSMVAGGK-RVSKALSYITGEMKECGEGLKDKSPVFQFLDWVLRGMSQVMFVNNPLSGIL Mm UT-B MEDSPTMAKVDRG-----ENQILSCRGRRCGFKVLGYVTGDMKEFANWLKDKPVVLQFMDWILRGISQVVFVSNPISGIL **. : . . . . . : $*:: *: * * * .: * * * * .:: * *: * *: * * * * * *: * * * * *: * *::$

Rsy UT $\frac{2}{\text { IIAALFLQNPWWAIAGCLGTAVSTLTALLLSQNRSAIAAGLHGYSAMLVGLLMAVFSTKGDWYWWLLFPVAVMSMTCPLL }}$ Rp UT IIAALFLQNPWWAIAGCLGTAVSTLTALLLSQDRSAIAAGLHGYSAMLVGLLMAVFSAKEDWYGWLLFPVAVMSMACPLI Rse UT IIAALFLQNQWWAIAGCLGTAVSTLTALLLSQDRSAIAAGLHGYSAMLVGLLMAVFSTKGDWYGWLLFPVAVMSMTCPLL Re UT IIAALFLQNPWWAIAGCLGTAVSTLTALLLSQDRSAIAAGLHGYSAMLVGLLMAVFSTKGDWYGWLLFPVAVMSMTCPLL Mm UT-A2 IVLGLFVQNPWWAISGCLGTVMSTLTALILSQDKSAIAAGLHGYNGVLVGLLMAVFSDKGNYYWWLLLPVIVMSMTCPIL Mm UT-B ILVGLLVQNPWWALCGCVGTVVSTLTALLLSQDRSAIAAGLQGYNATLVGILMAVFSNKGDYFWWLIFPVSAMSMTCPVF $*: \quad . *:: * * * * *: . * *: * * .: * * * * * *: * * *:: * * * * * * *: * * \ldots, * * *: * * * * * * *::: *_{*}:: * * \quad . * * *: * *::$

Rsy UT $\overline{\text { SSALGNIFGKWDLPVFTLPFNIAVCLHLAATGPNNVFFPTVDFRPTGVVPNISWSDVDIPQLLKAVPVGVGQVYGCDNPW }}$ Rp UT SSALGNIFSRWDLPVFTLPFNIAVCLHLAATGPNNEFFPTVDFRPTGVVPNISWSDVDIPQLLKAVPVGVGQVYGCDNPW Rse UT SSALGNIFSKWDLPVFTLPFNIAVCLHLAATGPNNEFFPTVDFRPTGVVPNMSWWDVDIPQLLKAVPVGVGQVYGCDNPW Re UT SSALGNIFSKWDLPVFTLPFNIAVCLHLAATGPNNEFFPTVDFRPTGVVPNISWSDVEISQLLKAVPVGVGQVYGCDNPW Mm UT-A2 SSALSTVFSKWDLPVFTLPFNIAVTLYLAATGHHNLFFPTTLLQPATTTPNITWSDIQVSLLLRAIPVGIGQVYGCDNPW Mm UT-B SSALSSVLSKWDLPVFTLPFNMALSMYLSATGHYNTFFPSKLFTPVSSVPNITWSELSALELLKSLPVGVGIYGCDNPW Rsy UT $\frac{7}{\text { SGGIMLVGLFVSPIICMHAAIGSAIGMLAGLSIAASFKTIYFGLWGYNSVLGCIAVGGMFYALTWQSHLLAIACALMCA }}$ Rp UT SGGIMLVGLFVSSPIICMHAAIGSAMGMLAGLSIAAPFETIYFGLWGYNAVLGCIAVGGMFYALTWQSHLLAIACALMCA Rse UT SGGIMLVGLFVSPIICMHAAIGSAMGMLAGLSIAAPFETIYFGLWGYNSVLGCIAVGGMFYALTWQSHLLAIACALMCA Re UT SGGIMLVGLFISSPIICMHAAIGSAMGMLAGLSIAAPFESIYFGLWGYNSVLGCIAVGGMFYALTWQTHLLAIACALMCA Mm UT-A2 TGGIFLVALFISSPLICLHAAIGSTIGMLAALSIATPFDSIYFGLCGFNSTLACIAIGGMFYVITWQTHLLAIACALFAA Mm UT-B TGGIFLCAILLSSPLMCLHAAIGSLLGVIAGLSLAAPFEDIYFGLWGFNSSLACIAIGGMFMALTWQTHLLALACALFTA $: * * *: * .::: * * *:: *: * * * * * *: *:: *, * *: *:, * . * * * * * *: *: *, * * *: * * * * .: * * *: * * * *: * * * *: *$ 10

Rsy UT $\overline{\text { YLGAALANVMAVVGLPSCTWPFCLTTLTFVLLTTNNSAIYKLPLSKVTYPEANRIYYLNLKKKKKY }}$

Rse UT YLGAALANVMAVVGLPSCTWPFCLTTLTFVLLTTNNSAIYKLPLSKVTYPEANRLYYLNQKKKKV Re UT YLGAALANVMAVIGLPSCTWPFCLTTLIFVLLTTNNPAIYKLPLSKVTYPEDNRIYYLNLKKERKKQ

Mm UT-A2 YLGAALANMLSVFGLPPCTWPFCLSALTFLLLTSNNPAIYKLPLSRVTYPEANRIYFLSQEKNRRASTITKYQAYDVS Mm UT-B YFGACMAHLMAVVHLPACTWSFCLATLLFLLLTTKNPNIYRMPLSKVTYSEENRIFYLQNKKRMVESPL--------$*: * * .: *:::: * . * * . * * * . * * *:: * *: * * *:: * . \quad * *:: * * *: * * * . * * *::: * .: * *$.

(a)

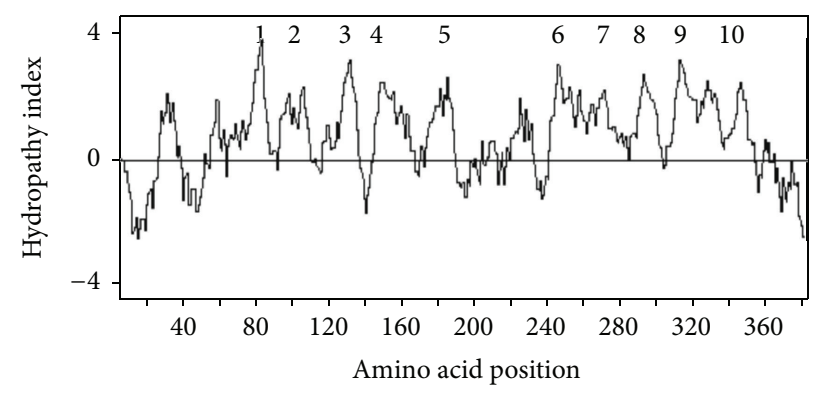

(b)

FIGURE 1: Primary structure of newly identified urea transporters (UT). (a) Deduced amino acid sequences of UTs from Rana sylvatica (Rsy UT), R. pipiens (Rp UT), and R. septentrionalis (Rse UT) were aligned with those from R. esculenta (Re UT; accession number CAA73322), mouse UT-A2 (Mm UT-A2; accession number AAM21206), and mouse UT-B (Mm UT-B; accession number AAL47138) using ClustalW in BioEdit v7.0.9.0. Amino acids that are identical (*), highly conserved (:), or moderately conserved (.) among all six sequences are identified. Box highlights a putative N-glycosylation site and horizontal bars indicate transmembrane regions. (b) Kyte-Doolittle hydropathy plot of Rsy-UT deduced amino acid sequences suggests the presence of ten transmembrane regions. 
TABLE 1: Relative tissue expression of mRNA encoding a putative urea transporter (UT) in three species of ranid frogs.

\begin{tabular}{lcccc}
\hline & Bladder & Kidney & Skin & Skeletal muscle \\
\hline R. sylvatica & $1.0 \pm 0.4^{\mathrm{a}}$ & $2.6 \pm 0.9^{\mathrm{a}}$ & $1.9 \pm 0.7^{\mathrm{a}}$ & $0.005 \pm 0.002^{\mathrm{a}}$ \\
R. pipiens & $1.9 \pm 0.4^{\mathrm{a}}$ & $0.2 \pm 0.07^{\mathrm{b}}$ & $0.3 \pm 0.02^{\mathrm{b}}$ & $0.003 \pm 0.001^{\mathrm{a}}$ \\
R. septentrionalis & $0.02 \pm 0.01^{\mathrm{b}}$ & $0.03 \pm 0.02^{\mathrm{c}}$ & $0.009 \pm 0.004^{\mathrm{c}}$ & n.d. \\
\hline
\end{tabular}

UT expression values were normalized to $R$. sylvatica bladder. Values are means \pm SEM; $n=5$ frogs per group. Different letters indicate means that were statistically distinguishable within a tissue $(P<0.05)$. n.d.: not detected.

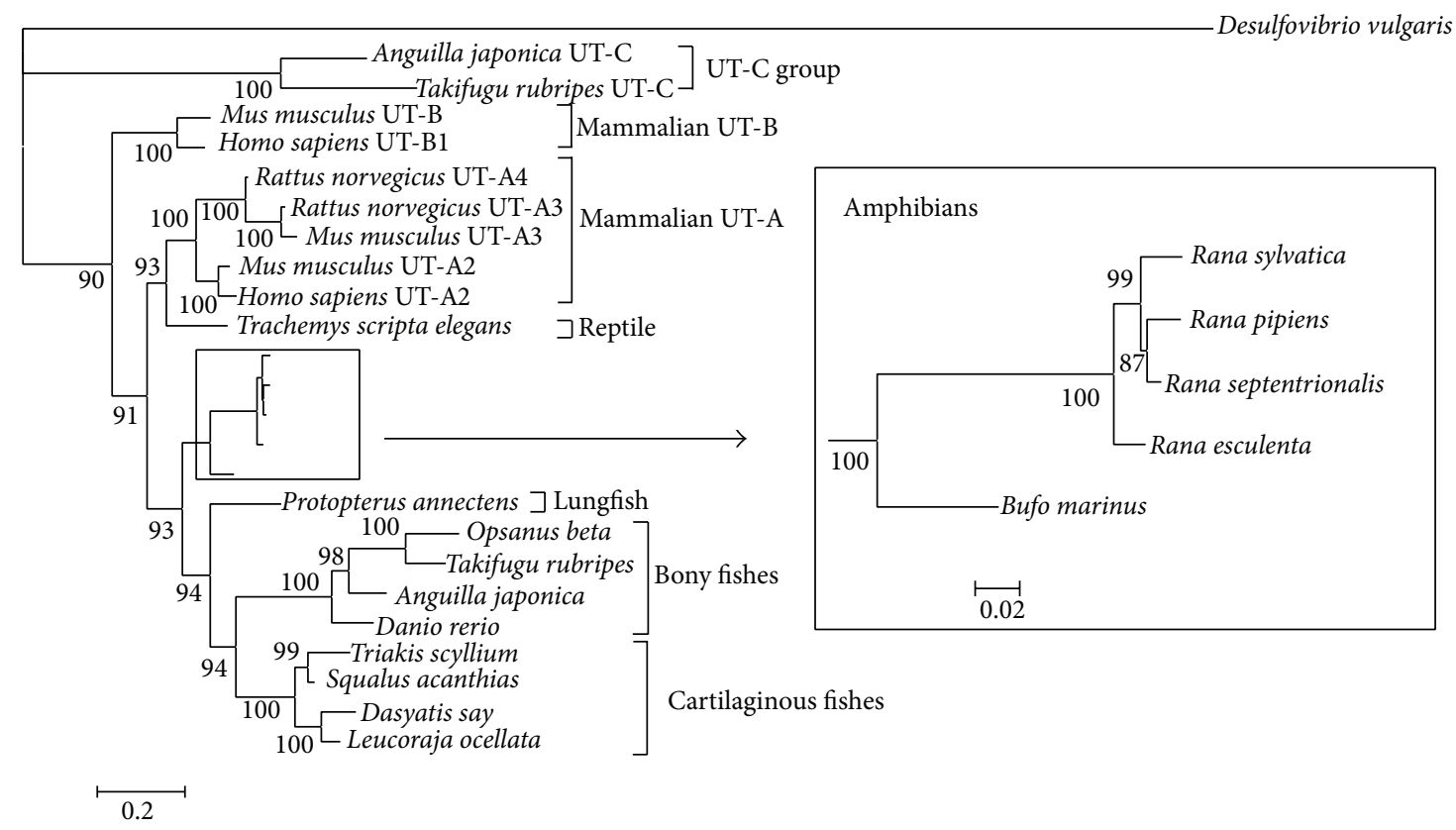

FIGURE 2: Phylogram illustrating the relatedness of novel UTs from Rana sylvatica, $R$. pipiens, and $R$. septentrionalis in comparison with known UTs from diverse taxa. This phylogram is a 50\% MJ Rule Consensus Tree constructed from codon aligned nucleotides implementing a GTR $+\mathrm{I}$ evolutionary model. Numbers at branch points are Bayesian posterior probabilities; scale bars indicate number of expected changes per site. Inset: amphibian clade expanded for clarity. Accession numbers for nucleotide sequences are as follows: D. vulgaris, CP002297; A. japonica UT-C, AB181944; T. rubripes UT-C, AB181945; M. musculus UT-B, AF258602; H. sapiens UT-B1, BC050539; R. norvegicus UT-A4, AF042167; R. norvegicus UT-A3, AF041788; M. musculus UT-A3, AF258602; M. musculus UT-A2, AF367359; H. sapiens UT-A2, X96969; T. scripta elegans, AB308450; R. sylvatica, JF755889; R. pipiens, JF755890; R. septentrionalis, JF755891; R. esculenta, Y12784; B. marinus, AB212932; P. annectens, EU716115; O. beta, AF165893; T. rubripes, NM_001032724; A. japonica, AB049726; D. rerio, AY788989; T. scyllium, AB094993; S. acanthias, AF257331; D. say, AY277796; L. ocellata, AY052552.

in tissues of $R$. septentrionalis, the relatively small amounts of UT protein corresponded to low levels of mRNA expression.

\section{Discussion}

One of the mechanisms underpinning survival of osmotic stress in amphibians is the ability to accumulate osmoprotectants, particularly urea. Hyperuremia results from increases in the production and/or retention of urea $[8,9]$, a process that likely involves UTs [10-12]. To clarify the mechanisms of urea transport and explore the importance of UT proteins in amphibian osmoregulation, we identified, determined the tissue distribution, and compared the abundance of a UT homolog from three species of ranid frogs. Our results help to elucidate the role of these proteins in urea metabolism and their possible contributions to amphibian adaptation to terrestrial environments.
4.1. Sequence Analysis. Analysis of the partial cDNA encoding the frog UTs resulted in a sequence of 380 amino acids that indicated ten transmembrane regions and contained an LP box, a conserved region of sequence which is characteristic of UTs [22] (Figure 1(a)). These UTs were highly similar to previously reported UTs from the anurans $R$. esculenta and $B$. marinus, as well as the mammalian UT-A2 and UTB. The high degree of similarity that the ranid UTs shared with the mammalian UT-A2 and the fact that they lacked the ALE domain characteristic of UT-B proteins [23] support the hypothesis that mammalian UT-A2 and nonmammalian UTs share a common ancestor [24]. Although these proteins were not characterized, their high degree of identity with characterized anuran UTs [10] suggests that they would function as a urea transport protein.

Phylogenetic analysis of Rsy-UT, Rp-UT, and Rse-UT revealed that these proteins group with other amphibian 


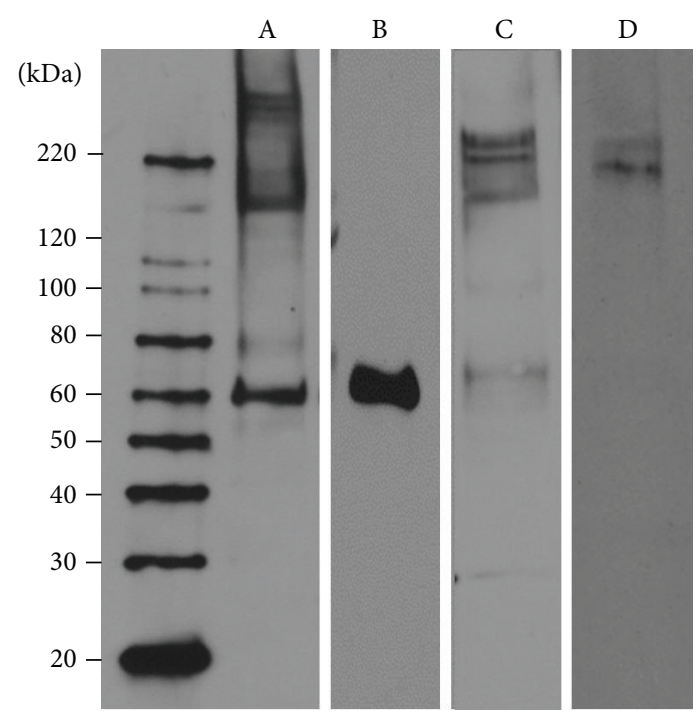

FIGURE 3: Immunoblot of UT protein in bladder ( $n=1$ each) of $R$. sylvatica (A), R. pipiens (B), and R. septentrionalis (C) using an antibody (Ab) designed against the ranid UT. (A) In R. sylvatica, a band was primarily detected at $60 \mathrm{kDa}$, although several bands of higher mass were also detected. (B) Only a single band at $60 \mathrm{kDa}$ was detected in $R$. pipiens. (C) In R. septentrionalis a faint band was detected at $60 \mathrm{kDa}$ and at higher masses. (D) The band at $60 \mathrm{kDa}$ in $R$. sylvatica was completely ablated in a competition assay in which the $\mathrm{Ab}$ was preincubated with a molar excess of its antigenic peptide; however, several bands of higher molecular mass remained. Only the bands at $60 \mathrm{kDa}$ were analyzed; see text for details.

UTs, forming a distinct clade separate from other taxa. Of note, the amphibian UTs, and UTs from other lower vertebrates, formed a clade sister to mammalian UT-A2, providing further support to the hypothesis that these proteins shared a common ancestor [24]. Additionally, results of our phylogenetic and sequence analyses suggest that the event leading to the appearance of multiple UT isoforms in mammals occurred sometime after amphibians in the evolutionary timescale.

4.2. Protein Distribution. Immunoblot analysis revealed the presence of the UT protein at various levels in several organs. In all species, relative protein levels were high in the osmoregulatory organs, especially urinary bladder, suggesting an importance for these transporters in regulating urea levels of the plasma and urine. A strong protein signal was detected in kidney and urinary bladder, with the bladder showing 3-23-fold greater protein levels than those in other tissues (Figure 4). Although the anuran kidney cannot produce hyperosmotic urine, it can reabsorb urea [8]. Our immunoblotting results, along with the finding that UTs are localized in the apical membrane of the early distal tubule of B. marinus [11], suggest that UTs are involved in renal reabsorption of urea in amphibians. The high level of UTs in the bladder of the frogs we examined bolsters findings for other anurans $[10,11]$. Urea is reabsorbed in the urinary bladder through a saturable process $[9,24]$, and the UTs provide a potential route through which urea can be transported from the bladder fluid to the extracellular fluid. The presence of these transporters in the kidney and urinary bladder may be especially important during urea accumulation as expression of UT proteins increases in these tissues in anurans under osmotic stress [11, 12]. Such an increase in UT protein would facilitate urea retention, one of the primary mechanisms involved in urea accumulation.

In $R$. sylvatica, UT protein was detected in another osmoregulatory organ, the skin. To our knowledge, this is the first report of UTs being expressed in anuran skin. Anurans are capable of transporting urea inwardly through the skin $[25,26]$, and, unlike in the bladder, this transport is an active process. The active urea transporter is thought to be located in the apical membrane of the skin, and it has been speculated that a facilitative UT is present in the basolateral membrane with the two transporters working in concert to move urea from the environment to the body fluids [27]. Our results are consistent with this hypothesis.

Occurrence of the UT protein in nonosmoregulatory organs indicates there is a role for UTs other than reabsorbing urea from the filtrate. We report for the first time the presence of UT protein in frog liver and lung tissue. These transporters are found in mammalian hepatocytes where they presumably facilitate urea efflux during ureagenesis [28]. Those in frog hepatocytes likely play a similar role and may be especially important during osmotic stress when urea is accumulated due in part to increased urea synthesis [7]. UTs are also found in the lung tissue of mammals [29]. Lung tissue of anurans has UT mRNA [11] as well as the expressed protein (Figure 4), but it is unclear what role this transporter may play in the lung of amphibians.

Skeletal muscle was the only tissue we examined in which no UT protein was detected in any of the species investigated. This finding was not unexpected as skeletal muscle plays no direct role in osmoregulation, urea production, or urea recycling. However, the uptake of urea may be important under certain stresses, such as freezing [5]. It is possible that UT protein was present at very low levels in our frogs and is only expressed at detectable levels during osmotic stress.

Contrary to the case with skeletal muscle, UT protein was detected in smooth muscle of the stomach, large intestine, and small intestine. UT mRNA has previously been found in anuran intestine, but not stomach [11]; however, this is the first report of the protein being detected in these tissues. UTs are present in the gastrointestinal tract of mammals where they apparently play a role in dietary nitrogen uptake and nitrogen recycling utilizing gut bacteria $[29,30]$. Although it is unknown if amphibians are capable of such nitrogen cycling, anurans do have an intestinal flora similar to that found in mammals [31], so it is possible that nitrogen recycling occurs in this group.

4.3. Species Variation. One aim of our study was to examine the relative importance of UT proteins in three closely related frog species with distinct natural histories [32]. $R$. sylvatica is predominately terrestrial, inhabiting woodlands away from permanent water. $R$. pipiens, often termed semiaquatic, spends most of its time in or close to water but 


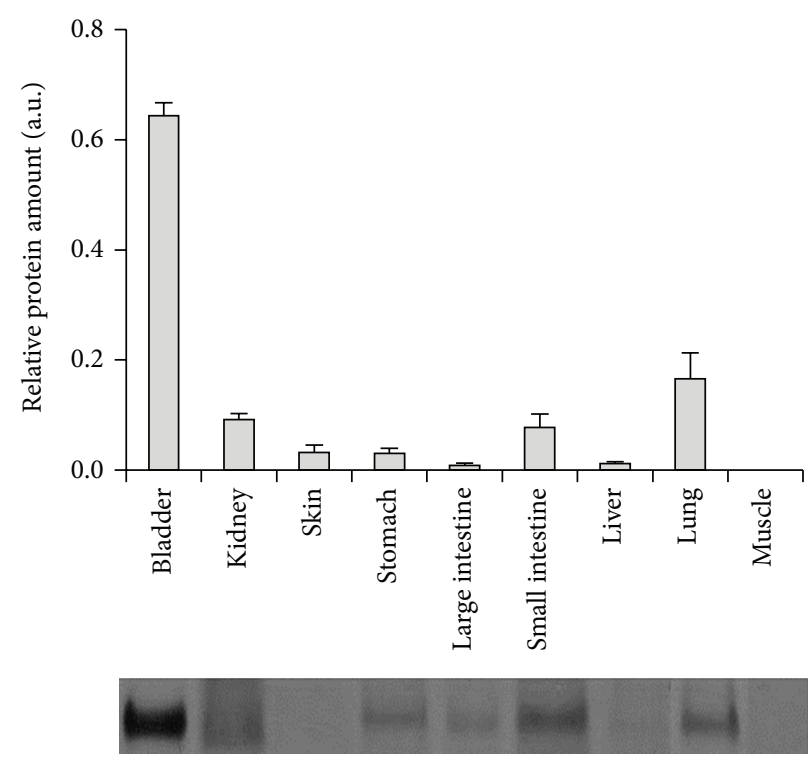

(a)
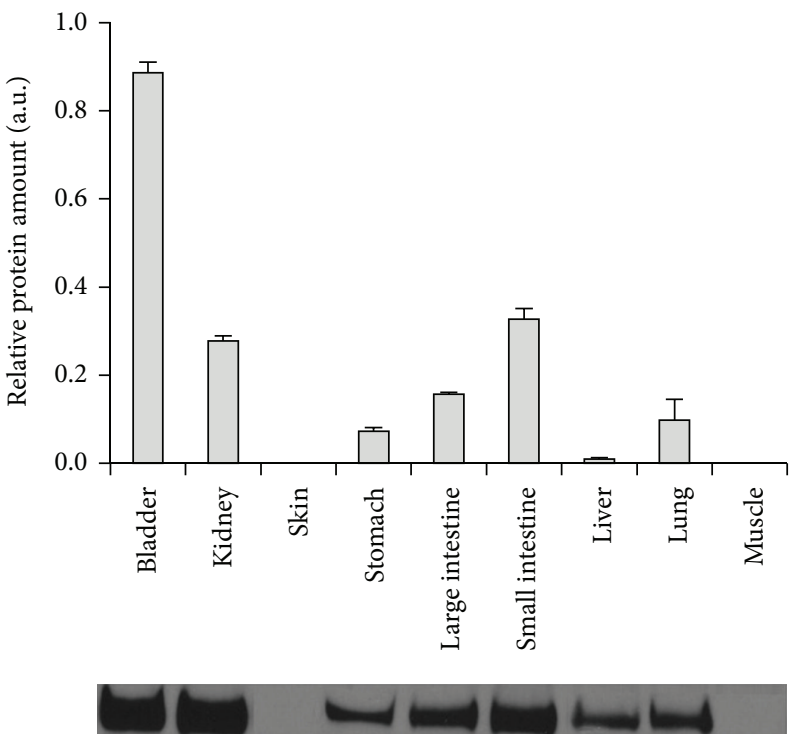

(b)

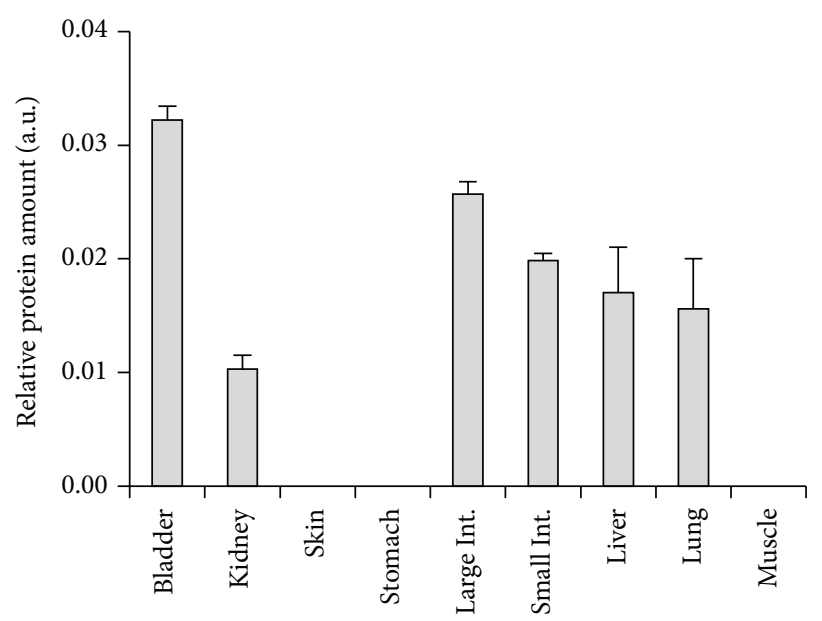

(c)

FIgURE 4: Tissue distribution of UT protein from Rana sylvatica (a), R. pipiens (b), and R. septentrionalis (c). For each species, abundance of UT protein was determined by densitometry and presented for each tissue as arbitrary densitometric units. Values represent the mean $\pm \operatorname{SEM}(n=4)$ intensity of the bands. Select immunoblots showing immunoreactive bands at $60 \mathrm{kDa}$ are presented below their respective quantification value. Note difference in the ordinate's scale in the plot for R. septentrionalis.

travels across land following rain events. $R$. septentrionalis, typically found in streams, ponds, and lakes, is highly aquatic. These differences in habitat preference among species are especially evident during hibernation. $R$. septentrionalis and $R$. pipiens are almost exclusively aquatic hibernators $[32,33]$, whereas $R$. sylvatica is restricted to terrestrial hibernacula [34]. Our findings indicate that degree of terrestrialism relates to the variation in UT abundance within the osmoregulatory organs. $R$. sylvatica consistently had the highest abundance of UT, R. pipiens showed intermediate to low levels, and the abundance of UT in $R$. septentrionalis was very low.

Variation in UT abundance among species potentially contributes to disparities in dehydration tolerance. UT expression increases in anurans under dehydrating conditions, suggesting they are important in survival of this stress $[11,12]$. R. sylvatica survives the loss of over half of its body water [35] and has an abundance of UTs, whereas $R$. septentrionalis is much less tolerant to desiccation [36] and has a relatively small transporter population in its tissues. The high abundance of transporters in $R$. sylvatica tissues presumably facilitates the movement and retention of urea during osmotic stress.

Due to their limited availability and logistical constraints, it was necessary to sample $R$. septentrionalis during the summer, whereas $R$. sylvatica and $R$. pipiens were sampled in late winter. However, it is unlikely that this difference 

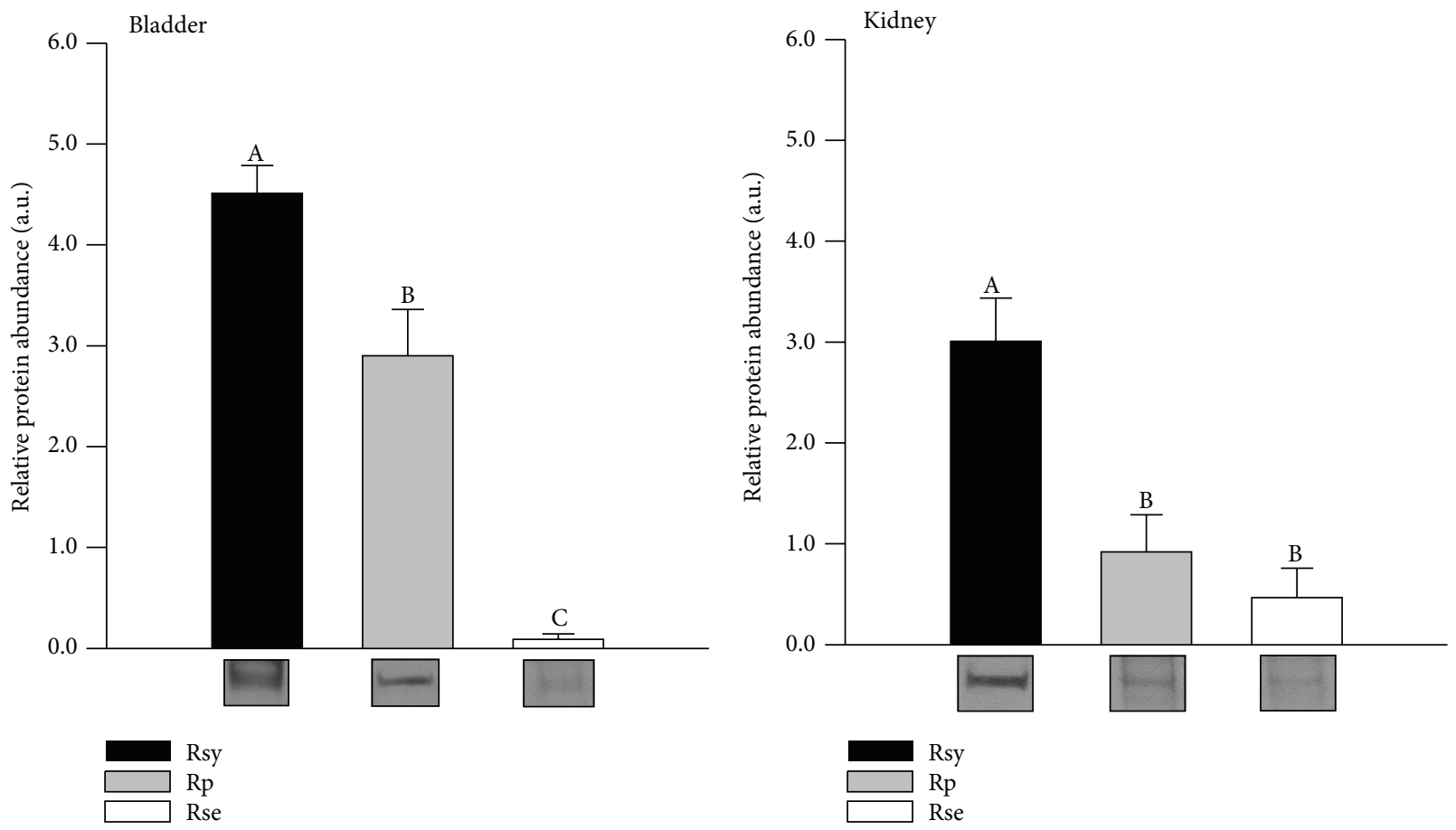

(a)

(b)

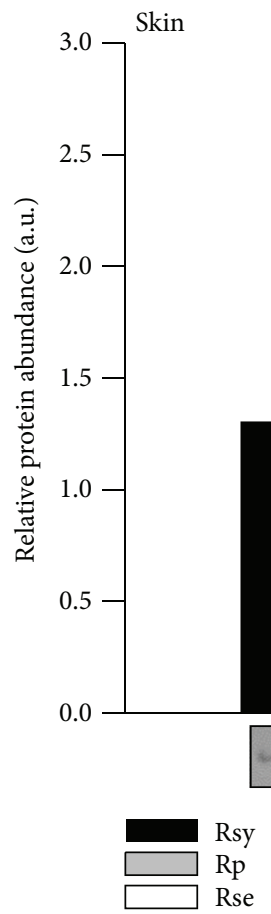

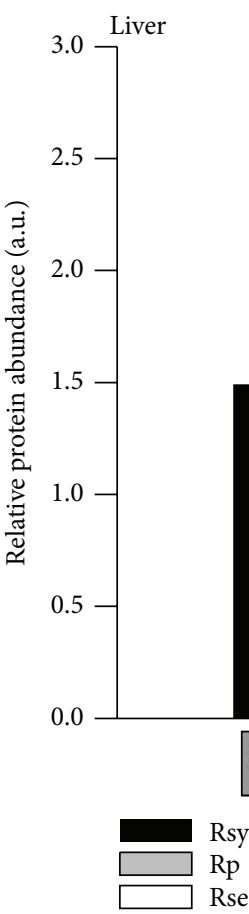

(c)

(d)

FIGURE 5: Relative abundance of UT protein in various tissues of Rana sylvatica (Rsy), R. pipiens (Rp), and R. septentrionalis (Rse) determined by immunoblotting. Tissue samples ( $30 \mu \mathrm{g}$ protein) were probed with an antibody designed against the ranid UT; relative abundance of UT protein, standardized to total protein, was determined by densitometry. Intensity values are means \pm SEM $(n=5)$. Different letters indicate means that were statistically distinguishable $(P<0.05)$. 
confounded our findings. In R. sylvatica, UT abundance is low in the winter, as compared to other seasons [12]; therefore, if all three species were matched for season, differences in UT abundance probably would have been enhanced. There was a significant difference $(F=19.1, P<0.0001)$ in plasma urea concentration among $R$. sylvatica, $R$. pipiens, and $R$. septentrionalis $(12.8 \pm 1.1,3.0 \pm 1.1,7.3 \pm 1.2 \mathrm{mM}$, resp.); however, uremia did not correspond with UT abundance. This further supports the view that species' differences in UT abundance were the result of phylogenetic and not physiological factors.

4.4. mRNA Expression. To further investigate the expression of UTs, mRNA levels were measured using qPCR in the skeletal muscle, as well as the osmoregulatory organs, urinary bladder, kidney, and skin. In most cases, we observed the expected correspondence between mRNA level and protein expression. For example, $R$. septentrionalis had the lowest levels of both UT protein and mRNA, and in no species did we detect UT protein in the skeletal muscle, which had exceptionally low levels of UT mRNA. The paucity of UT mRNA in $R$. septentrionalis lends further support to our conclusion that a phylogenetic difference in UT abundance occurs between species with different natural histories.

Presence of UT mRNA in the anuran kidney and urinary bladder was earlier reported [11]. However, to our knowledge, ours is the first report of UT mRNA expression in anuran skin and skeletal muscle. Unlike previous studies that examined UT mRNA in anurans, use of qPCR, a highly sensitive methodology, enables us to detect the very low mRNA levels present in the skeletal muscle and skin of the species we examined.

4.5. Conclusions. In this study, we identified a putative UT from $R$. sylvatica, $R$. pipiens, and $R$. septentrionalis, three species of true frogs that are adapted to distinct habitats. Despite differences in their natural histories, their UTs are highly conserved at the amino acid level and this high degree of identity is maintained when compared to more distantly related taxa. The conserved nature of UTs, along with their ubiquity among diverse organisms, suggests that these proteins have played an important evolutionary role in enabling organisms to physiologically adapt to their environment. Although the physiological roles of UTs in the osmoregulatory organs of anurans seem evident, a more in-depth examination is necessary to fully elucidate the function of these proteins, especially in the nonosmoregulatory organs. Among anurans, the relationship between UT abundance in tissues and terrestrialism likely contributes to differences in ability to survive osmotic stress.

\section{Conflict of Interests}

The authors declare that there is no conflict of interests regarding the publication of this paper.

\section{Acknowledgments}

The authors thank Tim Muir and Yuta Kawarasaki for assistance in collecting R. sylvatica, Catherine Bevier for collecting $R$. septentrionalis, and Shuxia Yi for technical advice. This study was supported in part by the National Science Foundation Grants IOB 0416750 and IOS 1022788 to J.P.C.

\section{References}

[1] M. S. Gordon, K. Schmidt-Nielsen, and H. M. Kelly, "Osmotic regulation in the crab-eating frog (Rana cancrivora)," Journal of Experimental Biology, vol. 38, pp. 659-678, 1961.

[2] C. Jørgensen, "Urea and amphibian water economy," Comparative Biochemistry and Physiology A, vol. 117, pp. 161-170, 1997.

[3] J. E. Grundy and K. B. Storey, "Urea and salt effects on enzymes from estivating and non-estivating amphibians," Molecular and Cellular Biochemistry, vol. 131, no. 1, pp. 9-17, 1994.

[4] J. P. Costanzo and R. E. Lee Jr., "Cryoprotection by urea in a terrestrially hibernating frog," The Journal of Experimental Biology, vol. 208, no. 21, pp. 4079-4089, 2005.

[5] J. P. Costanzo, M. Marjanovic, E. A. Fincel, and R. E. Lee Jr., "Urea loading enhances postfreeze performance of frog skeletal muscle," Journal of Comparative Physiology B: Biochemical, Systemic, and Environmental Physiology, vol. 178, no. 3, pp. 413420, 2008.

[6] T. J. Muir, J. P. Costanzo, and R. E. Lee Jr., "Osmotic and metabolic responses to dehydration and urea-loading in a dormant, terrestrially hibernating frog," Journal of Comparative Physiology B: Biochemical, Systemic, and Environmental Physiology, vol. 177, no. 8, pp. 917-926, 2007.

[7] J. Balinsky, "Adaptation of nitrogen metabolism to hyperosmotic environment in Amphibia," Journal of Experimental Zoology, vol. 350, pp. 335-350, 1981.

[8] K. Schmidt-Nielsen and P. Lee, "Kidney function in the crabeating frog (Rana cancrivora)," The Journal of Experimental Biology, vol. 39, pp. 167-177, 1962.

[9] S. Shpun and U. Katz, "Renal function at steady state in a toad (Bufo viridis) acclimated in hyperosmotic $\mathrm{NaCl}$ and urea solutions," Journal of Comparative Physiology B: Biochemical, Systemic, and Environmental Physiology, vol. 164, no. 8, pp. 646652, 1995.

[10] C. Couriaud, C. Leroy, M. Simon et al., "Molecular and functional characterization of an amphibian urea transporter," Biochimica et Biophysica Acta-Biomembranes, vol. 1421, no. 2, pp. 347-352, 1999.

[11] N. Konno, S. Hyodo, K. Matsuda, and M. Uchiyama, "Effect of osmotic stress on expression of a putative facilitative urea transporter in the kidney and urinary bladder of the marine toad, Bufo marinus," The Journal of Experimental Biology, vol. 209, no. 7, pp. 1207-1216, 2006.

[12] A. J. Rosendale, J. P. Costanzo, and R. E. Lee, "Seasonal variation and response to osmotic challenge in urea transporter expression in the dehydration- and freeze-tolerant wood frog, Rana sylvatica," Journal of Experimental Zoology A: Ecological Genetics and Physiology, vol. 317, no. 7, pp. A401-A409, 2012.

[13] J. M. Sands, "Mammalian urea transporters," Annual Review of Physiology, vol. 65, pp. 543-566, 2003.

[14] M. D. McDonald, C. P. Smith, and P. J. Walsh, "The physiology and evolution of urea transport in fishes," The Journal of Membrane Biology, vol. 212, no. 2, pp. 93-107, 2006. 
[15] M. Uchiyama, R. Kikuchi, N. Konno, T. Wakasugi, and K. Matsuda, "Localization and regulation of a facilitative urea transporter in the kidney of the red-eared slider turtle (Trachemys scripta elegans)," The Journal of Experimental Biology, vol. 212, no. 2, pp. 249-256, 2009.

[16] K. L. Manchester, "Use of UV methods for measurement of protein and nucleic acid concentrations," BioTechniques, vol. 20, no. 6, pp. 968-970, 1996.

[17] B. G. Hall, CodonAlign, Version 2.0, Bellingham Research Institute, Bellingham, Wash, USA, 2004.

[18] J. A. A. Nylander, MrModeltest v2, Evolutionary Biology Centre, Uppsala University, 2004.

[19] P. J. Waddell and M. A. Steel, "General time-reversible distances with unequal rates across sites: mixing $\Gamma$ and inverse Gaussian distributions with invariant sites," Molecular Phylogenetics and Evolution, vol. 8, no. 3, pp. 398-414, 1997.

[20] K. Tamura, D. Peterson, N. Peterson, G. Stecher, M. Nei, and S. Kumar, "MEGA5: molecular evolutionary genetics analysis using maximum likelihood, evolutionary distance, and maximum parsimony methods," Molecular Biology and Evolution, vol. 28, no. 10, pp. 2731-2739, 2011.

[21] T. D. Schmittgen and K. J. Livak, "Analyzing real-time PCR data by the comparative CT method," Nature Protocols, vol. 3, no. 6, pp. 1101-1108, 2008.

[22] G. Rousselet, P. Ripoche, and P. Bailly, "Tandem sequence repeats in urea transporters: identification of an urea transporter signature sequence," American Journal of Physiology, vol. 270, no. 3, pp. F554-F555, 1996.

[23] S. M. Bagnasco, "The erythrocyte urea transporter UT-B," Journal of Membrane Biology, vol. 212, no. 2, pp. 133-138, 2006.

[24] S. M. Bagnasco, "Role and regulation of urea transporters," Pflügers Archiv: European Journal of Physiology, vol. 450, no. 4, pp. 217-226, 2005.

[25] S. Shpun and U. Katz, "Urea transport across urinary bladder and salt acclimation in toad (Bufo viridis)," The American Journal of Physiology, vol. 258, no. 4, pp. R883-R888, 1990.

[26] F. Garcia-Romeu, A. Masoni, and J. Isaia, "Active urea transport through isolated skins of frog and toad," The American Journal of Physiology, vol. 241, no. 3, pp. R114-R123, 1981.

[27] J. Ehrenfeld, "Active proton and urea transport by amphibian skin," Comparative Biochemistry and Physiology A, vol. 119, no. 1, pp. 35-45, 1998.

[28] J. D. Klein, R. T. Timmer, P. Rouillard, J. L. Bailey, and J. M. Sands, "UT-A urea transporter protein expressed in liver: upregulation by uremia," Journal of the American Society of Nephrology, vol. 10, no. 10, pp. 2076-2083, 1999.

[29] R. T. Timmer, J. D. Klein, S. M. Bagnasco et al., "Localization of the urea transporter UT-B protein in human and rat erythrocytes and tissues," The American Journal of Physiology: Cell Physiology, vol. 281, no. 4, pp. C1318-C1325, 2001.

[30] N. Lucien, P. Bruneval, F. Lasbennes et al., "UT-B1 urea transporter is expressed along the urinary and gastrointestinal tracts of the mouse," American Journal of Physiology: Regulatory Integrative and Comparative Physiology, vol. 288, no. 4, pp. R1046-R1056, 2005.

[31] J. Gossling, W. J. Loesche, and G. W. Nace, "Large intestine bacterial flora of nonhibernating and hibernating leopard frogs (Rana pipiens)," Applied and Environmental Microbiology, vol. 44, no. 1, pp. 59-66, 1982.

[32] A. H. Wright and A. A. Wright, Handbook of Frogs and Toads of the United States and Canada, Comstock Publishing Associates, Ithaca, NY, USA, 1949.
[33] R. M. DeGraaf and D. D. Rudis, Amphibians and Reptiles of New England: Habitats and Natural History, University of Massachusetts Press, Amherst, Mass, USA, 1983.

[34] J. V. Regosin, B. S. Windmiller, and J. M. Reed, "Terrestrial habitat use and winter densities of the Wood Frog (Rana sylvatica)," Journal of Herpetology, vol. 37, no. 2, pp. 390-394, 2003.

[35] T. A. Churchill and K. B. Storey, "Dehydration tolerance in wood frogs: a new perspective on development of amphibian freeze tolerance," American Journal of Physiology, vol. 265, part 2, no. 6, pp. R1324-R1332, 1993.

[36] W. D. Schmid, "Some aspects of the water economies of nine species of amphibians," Ecology, vol. 46, pp. 261-269, 1965. 

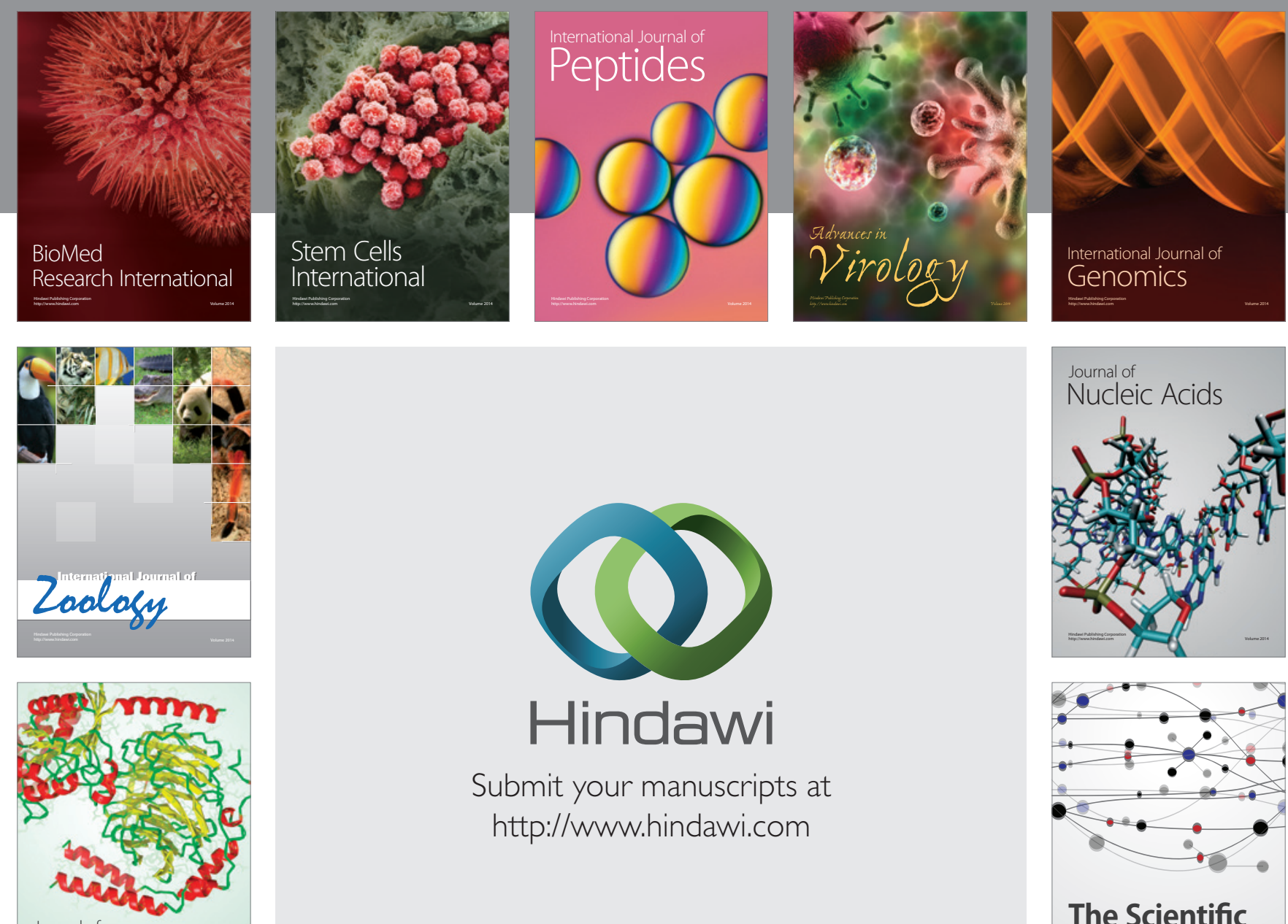

Submit your manuscripts at

http://www.hindawi.com

Journal of
Signal Transduction
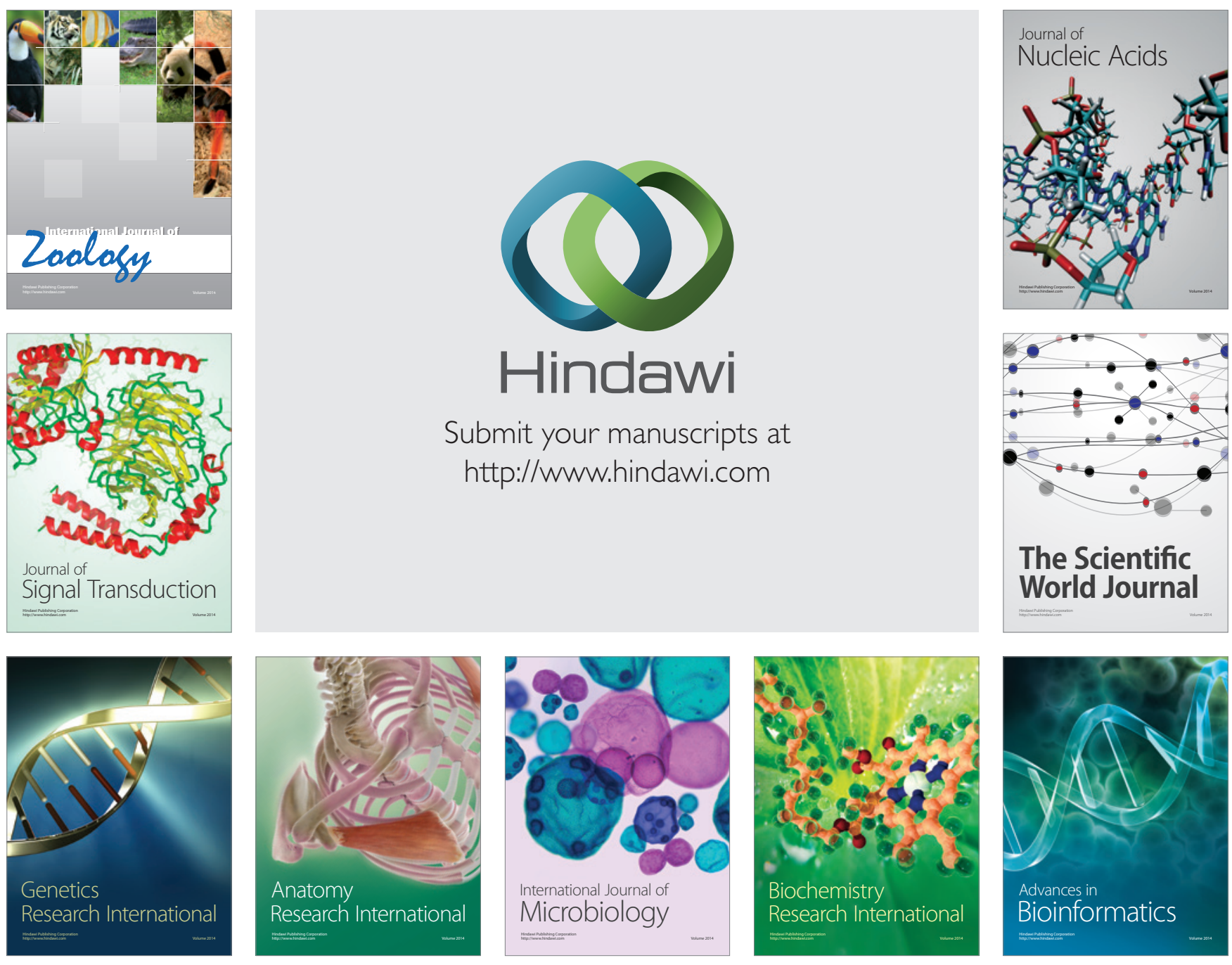

The Scientific World Journal
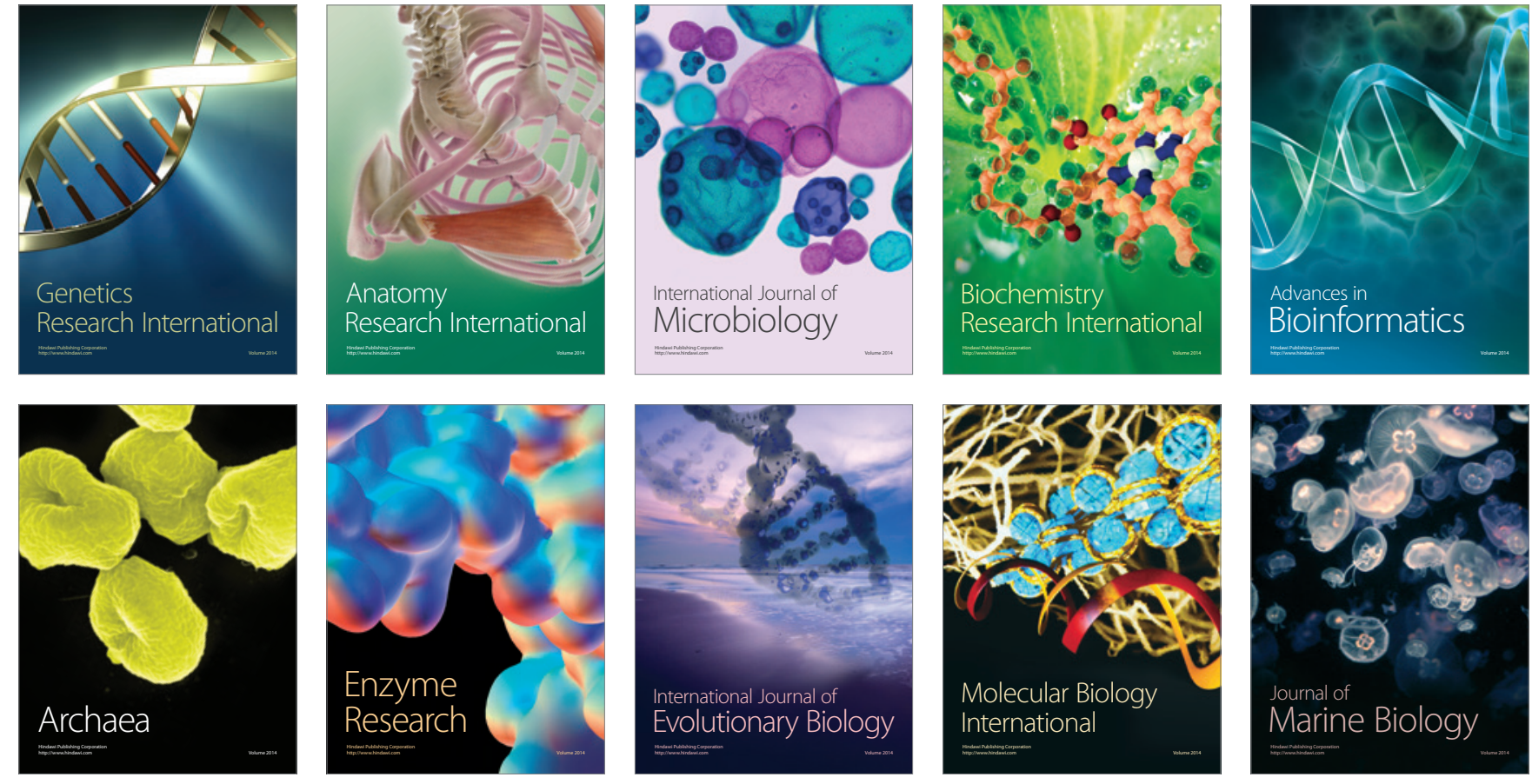